Archives of Agriculture and Environmental Science

\title{
A review on water and nitrogen use efficiency of potato (Solanum tuberosum L.) in relation to its yield and yield components
}

\section{Egata Shunka Tolessa}

Ethiopian Institute of Agricultural Research, Holetta Agricultural Research Center, Horticultural Research Division, Potato Research Program, PO Box. 2003, Addis Ababa, ETHIOPIA

E-mail: eshunka2007@gmail.com

\section{ARTICLE HISTORY \\ Received: 07 March 2019 \\ Revised received: 06 May 2019 \\ Accepted: 21 May 2019}

\section{Keywords}

Irrigation regime

Nitrogen rate

Nitrogen use efficiency

Water use efficiency

\begin{abstract}
Best potato growing condition available in Ethiopia compared to African countries. Poor resource and crop management was found one of the major production and productivity limiting factors. This review was conducted to show the gap available in optimum nitrogen rate utilization, limitation of irrigation water utilization, nitrogen and water use efficiency consideration in agronomic work of the country. In Ethiopia the production of potato was showing increasing due to land used for production increased but the productivity showed slight increase. Optimizing resource use efficiency by better management of water and nutrients through temporal and spatial irrigation and fertilization strategies in crop production is now getting concern in the world to enhance the profit of farm and minimize the cost of production. It is useful to consider some efficiency indices, in order to optimize the scheduling of water and nitrogen application. Determining nitrogen rates and irrigation water amount that improve the use of both water and nitrogen, and increasing knowledge of efficient use of resource could minimize the possible $\mathrm{N}$ losses thereby minimizing cost and increasing production profit. In the process of optimization, crop type to be grown and variety have also a remarkable contribution. On the last the nitrogen rate, irrigation regime and use efficiency of nitrogen and water were interrelated to each other and should be considered to gather with the yield and yield component of the potato for sustainable production with sufficient benefit.
\end{abstract}

(C)2019 Agriculture and Environmental Science Academy

Citation of this article: Tolessa, E.S. (2019). A review on water and nitrogen use efficiency of potato (Solanum tuberosum L.) in relation to its yield and yield components. Archives of Agriculture and Environmental Science, 4(2): 119-132, https://dx.doi.org/10.26832/24566632.2019.040201

\section{INTRODUCTION}

Potato (Solanum tuberosum L.) comes after wheat, rice and corn in production volume (Fabeiro et al., 2001). Potato production was about 327 million tons and 18.6 million hectares worldwide (FAO, 2006). It introduced to Ethiopia in 1858 (Pankhrust, 1964; Horton, 1987). Since then, high land farmers began potato production and potato product consumption when other crops failed. Estimated potato cultivated land was 160,000 hectares in 2001 (CSA, 2001) while it was reached $296,557.5$ ha in 2015
(CSA, 2015/16) with production volume of 572,000 ton to 3.66 million ton, respectively. Potato is temperate crop (Onder et al., 2005) and it also grows and yields well in cool and humid climates. It is a major food crop for many countries which satisfactorily grows from the tropics to the sub-polar. Among African countries, Ethiopia has the most potential of potato production because of the highlands comprises $70 \%$ of the country and home to higher percent of the population. Exploiting these production potentials will make the potato crop to play a key role in ensuring national food security (FAO, 2008). 
The ideal growth necessities for potato are high and nearly constant soil matric potential, high soil oxygen diffusion rate, adequate incoming radiation and optimal soil nutrients (Yuan et al., 2003). Among other environmental conditions, temperature and photoperiod are known factors that affect a range of physiological processes of the potato plant (Tsegaw, 2006). Optimum temperatures for foliage growth and net photosynthesis are $15-25^{\circ} \mathrm{C}$, and $20^{\circ} \mathrm{C}$ for tuberization. At temperature above $29^{\circ} \mathrm{C}$ tuberization is inhibited, foliage growth is promoted and net photosynthesis and assimilate partitioning to the tubers are reduced (Levy, 1992). In natural environment plants are subjected to numerous stresses that have a great influence on growth, development and yield of crops. These factors can be biotic and abiotic. Among these factors, drought and nutrients suboptimal use are major abiotic factors that limit crop production (Reddy et al., 2004).

Water is one of the most important restrictive factors of potato production and it is possible to increase production levels by well-scheduled irrigation programs throughout the growing season (Chowdhury et al., 2001; Panigrahi et al., 2001). Researchers report indicated that water impact on potato yield due to its influence on aerial parts (Deblonde et al., 1999; Lahlou et al., 2003). In relation to improving water and nitrogen use efficiency, some Authors reported. importance of drip irrigation mainly for vegetables and fruits (Shirie-e-Janagrad et al., 2006). Under limited rain fall supplementing irrigation water to satisfy the crop needs at each growth stages improve water supply to attain the required yields.

Potato production is sensitive to deficiencies and excesses of $\mathrm{N}$ (Biemond and Vos, 1992). According to Kleinkopf et al. (1981), excessive application of $\mathrm{N}$ at early stages delayed the linear tuber growth period from 7 to 10 days for indeterminate cultivars. In tuber bulking phase, potatoes needs a higher and continue supply of $\mathrm{N}$. Mid-season $\mathrm{N}$ shortage causes reduces canopy growth and premature senescence (Stark et al., 2004; Westermann, 2005). Excess mid-season $N$ supply decrease tuber bulking in favor of vegetative growth (Maynard et al., 1979; Waddell et al., 1999). Deficiencies or fluctuations of soluble nutrients (especially $\mathrm{N}$ ) increase pathogen and insect susceptibility, decrease tuber yields, and reduce tuber quality (Ojala et al., 1990). Potatoes' high amounts of fertilizer requirement are because of high nutrient demand and a superficial rooting system (Munoz et al., 2005; Pack et al., 2006). In addition to shallow rooting, potato cultivars have relatively inefficient nutrient and water use efficiency (Sattelmacher et al., 1990; Love et al., 2003). The outcome of low efficiency and high water/ fertilizer rates in potato is the potential cause for significant $\mathrm{N}$ contamination to surface (Honisch et al., 2002) and groundwater (Madramootoo et al., 1992). Although not studied as extensively as $\mathrm{N}$ in potatoes, high soil $\mathrm{P}$ is a potential environmental problem as well (Davenport et al., 2005). Determining nitrogen rates and irrigation water amount that improve the use of both water and nitrogen, and increasing knowledge of efficient use of resource could minimize the possible $\mathrm{N}$ losses thereby minimizing cost and increasing production profit.
Water use efficiency is the ratio of the tuber yield obtained to a unit of water consumed (Doorenbos and Pruitt, 1977). According to Hassan et al. (2002), a range of 69 to $233 \mathrm{~kg} \mathrm{ha}^{-1}$ $\mathrm{mm}^{-1}$ WUE of potato was indicated. Kiziloglu et al. (2006) reported WUE between 63.4 to $44.1 \mathrm{~kg} \mathrm{ha}^{-1} \mathrm{~mm}^{-1}$. WUE variability with different growing season was reported for potato crop (Nagaz et al., 2007). Nitrogen use efficiency (NUE) has two components (Moll et al., 1982) absorption efficiency or uptake [total $\mathrm{N}$ in the plant at maturity (tuber + haulm) divided by nitrogen supply or rate of fertilizer $\mathrm{N}$ ] and utilization efficiency [tuber weight divided by total $\mathrm{N}$ in the plant at maturity (tuber + haulm)]. Potatoes respond to farmyard manure and inorganic fertilizers application. Tuber yield advantage of $32 \%$ was reported by Bereke (1988), from application of $150 \mathrm{~kg} \mathrm{~N}$ and $66 \mathrm{~kg}$ $\mathrm{P}_{2} \mathrm{O}_{5} /$ ha under rain-fed conditions compared to control. Haramaya clay soil optimum potato production require application of $87 \mathrm{~kg} \mathrm{~N}$ and $46 \mathrm{~kg} \mathrm{P}_{2} \mathrm{O}_{5} / \mathrm{ha}$ (Getu, 1998). Recommended rate of $110 \mathrm{~kg} / \mathrm{haN}$ and $90 \mathrm{~kg} \mathrm{P}_{2} \mathrm{O}_{5} / \mathrm{ha}$ is applied for potato production on the black soil of Holetta (IAR, 2000). Hence, fertilizer requirement varies across locations and varieties under cultivation. Efficient use of available resources is one of the most important objectives in the sustainable management of cropping systems. In Ethiopia, irrigation for potato production is not well known (Peter et al., 2009). Where small irrigated systems started to be practiced, there was excessive and shortage problem (Geremew, 2008). On the other hand, less water irrigation facilitate low quality tuber yield due to reduced leaf area and/or reduced photosynthesis per unit leaf area (Van Loon, 1981). Optimizing the water and nitrogen deliver is vital issue as it varies with a lot of outside and crop factors. There is inadequate information about crop water and nitrogen use effectiveness in Ethiopia. The nitrogen rates of improved potato varieties are similar while application of $138 \mathrm{~kg} \mathrm{~N}$ and $20 \mathrm{~kg}$ P/ha are recommended for optimum productivity of Gorebiella variety on the vertisols of Debere Berhan under rain fed conditions (Zelalem et al., 2009). On the other hand, other varieties are cultivated by applying blanket recommendation. Achieving most advantageous nitrogen rate applications should be quantified as it varying with soil, crop and water available to the crop. In addition to this, the information about impact of $\mathrm{N}$-fertilizer application and irrigation regimes on water and nitrogen use efficiency is also inadequate. Therefore, the present review was conducted to show the gap available in optimum nitrogen rate utilization, limitation of irrigation water utilization, nitrogen and water use efficiency consideration in agronomic work of the country.

\section{WATER AND NITROGEN USE EFFICIENCY OF POTATO}

Irrigation regimes are important in determining plant uptake ability of nitrogen available in the soil since well watered crop is more capable to take benefit of applied fertilizers (Luisa et al., 1997). This aspect helps especially, to estimate nitrogen use efficiency at different irrigation water regimes and consequently the environmental impact of nitrogen fertilizer. Optimizing resource use efficiency by better management of water and nutrients through temporal and spatial irrigation and fertiliza- 
tion strategies in crop production is now getting concern in the world. Nitrogen is one of the macro nutrients greatly affecting yield and yield components of potato. According to Zelalem et al. (2009) there was significant increase in aboveground and underground biomass of potato due to $\mathrm{N}$ and $\mathrm{P}$ application. These authors added that increment of aboveground biomass by $224.5 \%$ and $32 \%$ tuber yield due to application of $207 \mathrm{~kg} \mathrm{~N} /$ ha and $60 \mathrm{~kg} \mathrm{P} /$ ha compared to the control. Canopy dry matter yield increase response to $\mathrm{N}$ fertilization is reported by Millard and Marshall (1986). They also indicated that the increment of marketable yield by $176 \%$ and total tuber yield by $119 \%$ as a result of increment of application of nitrogen rates from 0 to $207 \mathrm{~kg} \mathrm{~N} / \mathrm{ha}$. Nutrient and water supply affected transpiration water use efficiency (Brück et al., 2008). According to Brück et al.(2008) potato varieties decreased shoot dry matter (DM), leaf area and specific leaf nitrogen under conditions of low water supply and high WUE was indicated. In another experiment the authors grew plants with three different levels of nitrogen supply, shoot DM increased significantly from 16 to $37 \mathrm{~g}$, along with leaf area and SLN (Specific Leaf Nitrogen) as the rate of nitrogen application increased. At a lowest level of nitrogen supply (NO), WUE was significantly lower.

Rational use of natural resources, especially water and nutrients, is one of the most important objectives in the sustainable management of cropping systems. To achieve these objectives it is useful to consider some efficiency indices in order to optimize the scheduling of water and nitrogen application. Battilani et al. (2004) the effects of three treatments (Rain-fed, ETC $=120 \%$, $\mathrm{ETC}=100 \%$ followed by $\mathrm{ETC}=70 \%$, with a change of irrigation regime at an average tuber diameter of $35 \mathrm{~mm}$ ) on four varieties (one determinate and three indeterminate), the WUE of the irrigated plots was $38 \%$ lower than under rain fed conditions, depending on rain distribution during the growth cycle and whether the WUE is calculated on fresh matter or on dry matter (DM) base. According to Darwish et al. (2006) there was observed 69 to $233 \mathrm{~kg}$ ha-1 mm-1, the lowest WUE from $60 \%$ of full irrigation regimes while 80,100 and $120 \%$ irrigation provided maximum water use efficiency. Kirda (2002) successful deficit irrigation of potato provided 1.06 relative water use efficiency compared to full water supply in drip irrigation. Onder et al. (2005) reported decreased WUE due to increase in water supply. Related reports were mentioned by many Authors (Kashyap and Panda (2003) and Yuan et al. (2003). The highest WUE was obtained from application of irrigation when $30 \%$ of the available water was consumed (Erdem et al., 2006). Water use efficiency is not varying much among water stresses (Kashyap and Panda, 2003). Kang et al. (2004) and Onder et al. (2005) also registered similar WUE values for potato. Biomass production was significantly reduced in drought-treated plants (Bergaten et al., 2003).

\section{Water use efficiency}

Water use efficiency (WUE) is a broad concept which has many definitions. In production, WUE is estimated considering harvested crop yield and water supplied. It is calculated as a ratio of tuber yield, biomass dry or fresh weight to water consumed in potato production (Doorenbos and Pruitt, 1977). Improving WUE in crop production requires an increase in water productivity which in turn increases marketable crop yield while reducing water losses from the plant rooting zone. Water use efficiencies (WUE) vary with irrigation regimes and planting time (Steyn et al., 2007). Van Loon (1981) reported a water use efficiency of $127 \mathrm{~kg} \mathrm{ha}^{-1} \mathrm{~mm}^{-1}$ in unstressed treatment of autumn planting. Walker et al. (1991) pointed out that efficient water use is optimizing water usage and ensuring efficiency in its use. One mechanism of proper resource utilization is supplementing rainfall by irrigation water to satisfy the crop needs, in growth stages is necessary to attain the maximum yields, when there is shortage of rainfall in the growing season as it is a basic operation to avoid water shortage and over-irrigation which can reduce yields declining through reducing soil aeration that in turn reduce uptake (water and nutrient) and increasing nitrogen leaching (Shirie-e-Janagrad et al., 2006). The other basic issue is identifying management practices that promote the efficient use of both water and nitrogen, and developing wisdom of efficient use of resource which minimize the potential losses and will create safe environment, thereby reducing production cost and increasing farm profit.

\section{Accounting for water use and productivity}

Water accounting is a process of quantifying the depletion and productivity of water in a water basin context (Gebreegziabher, 2005). It is a supporting methodology used in assessing impact of field level intervention and performance of irrigation agriculture. The water accounting methodology works depending on water balance approach which considers inflows and outflows from different streams and levels such as irrigation systems or fields (Molden, 1997). Water accountings in greenhouse include the water balance components of irrigation water and water depletion which encompass evaporation, deep percolation, transpiration and incorporation to product. It also holds precipitation in actual field.

\section{Water use performance indicators}

The water use performance indicators of irrigation benefits evaluation include quantification of irrigated amount, drainage volumes, crop yields, water costs and enterprise returns (Skewes and Meissner, 1998). Some examples of water use efficiency indicators are provided in Table 1.

\section{Crop evapotranspiration and irrigation requirements}

Crop consumptive water use is the sum of water transpired by the plants, the water evaporated from the soil and the fraction of water held by the plant tissues. It may include amount of water evaporated from plant parts when overhead irrigation is used. Plants use $1 \%$ of water taken up for their metabolic activity. Consequently, in applied approach crop water consumption corresponds to crop Evapotranspiration (ETC). Potato ETC can be estimated using weather data and is the amount of water to be applied during the growing season in order to assure poten- 
tial tuber yields at a given site. Potato ETC is important to consider in irrigation as a well-developed strategy to improve the effectiveness of production. Local atmospheric conditions, surface soil wetness, crop type, stage of growth, and the amount of crop cover are the factors that govern the daily fluctuations of potato Evapotranspiration (Wright and Stark, 1990). According to Wright and Stark (1990) the ETC increased as the leaf area and transpiration increased and reached near-maximum levels just before effective full cover. The leaf area index (LAI) reached 3.5 by effective full cover coincident with the highest daily ETC of $8.5 \mathrm{~mm}$. Potato ETC varies greatly from region to region and season to season. Seasonal potato ETC in the humid Wisconsin area for June through August ranged from 293 to $405 \mathrm{~mm}$ during 3 years of study (Tanner, 1981). The maximum daily potato ETC measured by a weighing lysimeter in a sub-humid region in India is found to be $4.24 \mathrm{~mm} \mathrm{~d}^{-1}$ (Kashyap and Panda, 2001). Under a hot and dry climate in northeastern Portugal, peak ETC rates reached $12-13 \mathrm{~mm} \mathrm{~d}^{-1}$ on the days immediately following irrigation, but crop water use declined logarithmically with time to about $3 \mathrm{~mm} \mathrm{~d}^{-1}$ within 5 days (Ferreira and Carr, 2002). Growth-stage specific crop coeffi- cients $(\mathrm{Kc})$ and the water balance method provided a valuable tool in scheduling overhead irrigation of Russet Burbank potatoes in the Columbia Basin of Oregon (Hane and Pumphrey, 1984). According to Simonne et al. (2002), Kc values ranged from 0.3 at emergence to 0.8 during maximum leaf area, and declined as the crop matured. ETC is usually calculated by the product of Kc and ETO (reference evapotranspiration), or as a function of a number of climatic elements to provide the atmospheric potential demand. ETC is an essential agro meteorological index, which can be used to determine both the amount of water to be applied and the irrigation frequency for a particular crop and site.

Total ETC in mm also vary with climate, crop, soil and other factors. Onder et al. (2005) reported the highest evapotranspiration of $473-391 \mathrm{~mm}$ at full irrigation of 2000 and 2002 years, respectively. Erdem et al. (2005) reported that in the non-stressed treatments, the amount of total irrigation water applied and seasonal ETC was 417 and $524 \mathrm{~mm}$, respectively for drip irrigation. Early research reported that seasonal potato ETC ranged from 350 to $800 \mathrm{~mm}$ for different climatic and environmental conditions (Fabeiro et al., 2001; Onder et al., 2005).

Terms
Gross Production Water Use efficiency $=\frac{\text { Key Definitions }}{\text { Total Water Applied (ML) }}$
Irrigation Water Use efficiency $=\frac{\text { Total Product (kg) }}{\text { Irrigation Water Applied (ML) }}$
Marginal Irrigation Water Use efficiency $=\frac{\text { Marginal Production due to irrigation (kg) }}{\text { Irrigation Water Applied (ML) }}$
Crop Water Use Index /efficiency $=\frac{\text { Marginal Production due to irrigation (kg) }}{\text { Irrigation Water Applied (ML) }}$
Economic Gross Production Water Use efficiency $=\frac{\text { Economic return (\$) }}{\text { Total Water Applied (ML) }}$
Marginal Irrigation Economic Water Use efficiency $=\frac{\text { Marginal return due to irrigation (\$) }}{\text { Irrigation Water Applied (ML) }}$
Economic return (\$)

Source: Raine,1999; as cited in Gebreegziabher, 2005. 
Table 2. Soil water contents for agricultural soils.

Soil water content on volumetric basis (\%)

Texture class

\begin{tabular}{cccccccc}
\hline \multicolumn{2}{c}{ Field capacity } & \multicolumn{2}{c}{$\begin{array}{c}\text { Permanent } \\
\text { wilting point }\end{array}$} & \multicolumn{2}{c}{ Available water } & \multicolumn{2}{c}{$\begin{array}{c}\text { Water holding } \\
\text { capacity }(\mathrm{mm} / \mathrm{m})\end{array}$} \\
\hline Average & Range & Average & Range & Average & Range & Average & Range \\
\hline 12 & $7-17$ & 4 & $2-7$ & 8 & $5-11$ & 0.96 & $0.60-1.32$ \\
14 & $11-19$ & 6 & $3-10$ & 8 & $6-12$ & 0.96 & $0.72-1.44$ \\
23 & $18-28$ & 10 & $6-16$ & 13 & $11-15$ & 1.56 & $1.32-1.80$ \\
26 & $20-30$ & 12 & $7-16$ & 15 & $11-18$ & 1.80 & $1.32-2.16$ \\
30 & $22-36$ & 15 & $9-21$ & 15 & $11-19$ & 1.80 & $1.32-2.28$ \\
32 & $29-35$ & 15 & $12-18$ & 17 & $12-20$ & 2.04 & $1.44-2.40$ \\
34 & $30-37$ & 19 & $17-24$ & 15 & $12-18$ & 1.80 & $1.44-2.16$ \\
36 & $29-42$ & 21 & $14-29$ & 15 & $11-19$ & 1.80 & $1.32-2.28$ \\
36 & $32-39$ & 21 & $19-24$ & 15 & $10-20$ & 1.80 & $1.20-2.40$ \\
\hline
\end{tabular}

Source: Jensen et al. (1990)

Irrigation of crops

Ideally, a soil should hold enough water to facilitate plant growth, and have good drainage system for excess water. Soils ability to store water varies depending on their texture (Table 2). Most soil profiles are a mixture of the various textural classes, and the total water storage capacity depends on the cumulative storage capacities of the various layers within the profile. So water irrigators should consider the water holding capacity of the soil.

Soil moisture status is expressed in percent total available soil water (TAW) content or soil water tension (SWT). Total available soil water content is the amount of water that plants can extract from a given volume of soil in the crop effective rooting zone. Total available soil water is usually expressed as a percent between "field capacity" (100\%) and "permanent wilting point.

Soil water tension is the force roots exert to extract water from the soil. At "field capacity" (100\% TAW), the SWT is often between 10 and $25 \mathrm{kPa}$ depending on soil type and the method of determination. Soil water is not available at the "permanent wilting point", generally assumed to be at a SWT of 1,500 kPa. Soil water tension can be measured directly using tensiometers or granular matrix sensors (Shock, 2003).

Total available water (TAW)

TAW is the amount of water that a crop can extract from its root zone and its magnitude depends on the type of soil and rooting depth (FAO, 1998). It is stated as:

$\mathrm{TAW}=1000(\theta \mathrm{fc}-\theta \mathrm{wp}) \times \mathrm{Ze}$

Where TAW = the total available soil water in the root zone $(\mathrm{mm}) ; \theta \mathrm{fc}=$ moisture content at field capacity $(\mathrm{m} 3 \mathrm{~m}-3) ; \theta \mathrm{WP}=$ moisture content at wilting point $(\mathrm{m} 3 \mathrm{~m}-3)$; and $\mathrm{Ze}=$ rooting depth (m).

\section{Readily available soil water (RAW)}

Initial soil moisture depletion or readily available water (RAW) is the fraction of TAW that a crop can extract from the root zone without suffering water shortage (FAO, 1998). It can be stated as:

RAW $=p^{*} T A W$

Where TAW = the total available soil water in the root zone $(\mathrm{mm}) ; \mathrm{RAW}=$ the readily available soil moisture in the root zone $(\mathrm{mm})$ and $\mathrm{p}=$ average fraction of TAW that can be depleted from the root zone before moisture stress occurs. The factor $p$ differs from one crop to another. It varies from 0.3 for shallow rooted plants to 0.7 for deep-rooted plants. Generally a value of 0.5 for $p$ is commonly used for many crops (Gebreegziabher, 2005). It can also be 0.5-0.3 (Doorenbos and Kassam, 1979) to optimize yield and 0.35 (Curwen, 1993) as well as 0.45 (Kashyap and Panda, 2002) on sandy loam soil in a sub-humid sub-tropical region in order to attain maximum water use efficiency. It can also be 0.4 (Jim Bauder and Linzy, 2010). 0.25- 0.50\% P was used to calculate readily available soil water from total available soil water (FAO AGL, 2002). The allowable depletion fraction (p) varies with soil type, crop stage and climate.

Irrigation water amount also depends on effective rooting depth. According to Gebreegziabher (2005) $100 \mathrm{~cm}$ was used as effective root depth for potato and other vegetables in Tigiray, northern Ethiopia. As potato is shallow rooted crop (Tanner et al., 1982) about $90 \%$ of the root length of potato is found in the top $25.4 \mathrm{~cm}$, while most other crops root deeper. According to Wang (2006) higher potato root length $(0-60 \mathrm{~cm})$ was reported. But it can grow for maximum length of $40-60 \mathrm{~cm}$ according to Ayers and Westcott (1985) and higher root density occur between 15 and $30 \mathrm{~cm}$ (Bishop and Grimes, 1971-74). FAO AGL (2002) use $30 \mathrm{~cm}$ irrigation depth from 1-100 days after planting and $60 \mathrm{~cm}$ after 101days after planting for potato growing.

\section{Irrigation scheduling}

Nitrogen rates and irrigation regimes are among the basic factors considerably affecting the water and nitrogen use efficiencies of varieties. According to Brück et al. (2001) report decreased shoot dry matter (DM), leaf area, nitrogen up take efficiency and increased WUE was recorded under low water supply. On the other hand, they reported significantly lower 
WUE under lowest level of nitrogen supply. In experiment of comparing control or zero nitrogen application with treatment applied nitrogen to the requirement of the crop, increase of WUE from dry matter and yield was indicated with increasing nitrogen supply (Caviglia and Sadras, 2001). Similar results was reported by Kelm et al. (1999-2000) in which the lowest WUE was indicated under none fertilized while highest was obtained from highest rates. They also narrated reason for lowest WUE under lowest application of nitrogen and it was due to very low total dry matter production and higher stomata opening under $\mathrm{N}$ stress, which was reflected in the observed higher transpiration rate. Plants mostly suffer from nutrient deficiencies (especially $\mathrm{N}$ and $\mathrm{P}$ ), which could be regulated by climate and environment changes, fundamentally increased water stress (Wu et al., 2009) due to the close relationships between water and nutrient availabilities. Nitrogen $(N)$ fertilizer plays a crucial role in enhancing canola yield. Water management has a severe effect on $\mathrm{N}$ movement. But well watered crop is more capable to take benefit of applied fertilizers (Luisa et al., 1997). Even though leaching of nitrate due to heavy rainfall cannot be completely prevented, following the $\mathrm{N}$ management strate-gies can minimize the losses of nitrogen. Some of the nitrogen losses minimization management strategies considerations for irrigated potatoes are determination of nitrogen rate, timing of $N$ applica-tion, and use of diagnostic procedures to determine $\mathrm{N}$ needs during the growing season, effective water management, sources of $\mathrm{N}$, and establishment of a cover crop after harvest (BMPNU, 2008). However, over-irrigation even with optimum $N$ rate and proper application time can cause substantial leaching losses. Therefore, effective water scheduling techniques based on soil moisture content and demand by the crop should be followed to prevent such losses (BMPNU, 2008).

Irrigation of crops sensitive to water stress requires systematic scheduling of irrigation decisions. There are three methods for matching irrigation with crop water requirements (Pereira and Shock, 2006). These are measuring how much water the soil contains, monitoring some attribute of the plant that is related to water deficits, calculating how much water the atmosphere can extract from a well-watered crop. These types of scheduling are also described by other authors as atmospherical based, plantbased, or soil-based data matching or scheduling (Shae et al., 1999). Plant data may include canopy temperature, xylem water potential, and visible wilting. Soil-based data include soil water content and soil water tension (SWT). In practice, plant, soil, and atmospheric data are often used concurrently, especially when changes in irrigation schedules are required to adjust for changes in crop water use. Soil-based irrigation scheduling methods range from the simple "feel" method to such technologically advanced methods as the neutron probe and time-domain reflectometry (Shock et al., 1998). Tensiometers and gypsum blocks provide technology and cost benefit between these extremes, but they have limitations for practical use by growers.

\section{Tensiometer}

Measures soil moisture (the soil moisture tension) directly
(Shock, 2003). The moisture level at which irrigation starts can be controlled by installing tensiometer in most irrigations and the best lower limit water potentials based on potato yield and grade responses to irrigation ideally as irrigation criteria includes $50 \mathrm{kPa}$ using furrow irrigation on loam soil in California (Timm and Flockner, 1966), 50 to $60 \mathrm{kPa}$ using sprinklers on silt loam in Oregon (Eldredge et al., 1992, 1996), 25 kPa using sprinklers on silt loam in Maine (Epstein and Grant, 1973), $60 \mathrm{kPa}$ and $30 \mathrm{kPa}$ using furrow and drip irrigation, respectively, for silt loam in Oregon (Shock et al., 2002), and 20 kPa using sprinklers on sandy loam in Western Australia (Hegney and Hoffman, 1997).

\section{Gravimetric soil moisture measurement}

It is the standard way soil water measuring methods which involves taking soil sample, weighing it before any water is lost, and drying it in an oven to weighing it again (Hignett and Eventt, 2008). The mass of water lost on drying is a direct measure of the soil water content (Equation 3).

$$
\theta \mathrm{m} \frac{\mathrm{W} 1-\mathrm{W} 2}{\mathrm{~W} 1}
$$

Where, $\theta \mathrm{m}=$ Gravimetric soil water content, $\mathrm{W} 1$ and $\mathrm{W} 2$ are weight of wet and dry soil, respectively.

The above soil moisture value is on mass basis water content of a field soil which can be used for comparative purposes and is useful when soil volume changes, as with tillage. However, for most irrigation, crop water use, and irrigation and water use efficiency work, what is required is the volume of water in a certain volume of soil or the equivalent depth of water in a certain depth of soil (Hignett and Eventt, 2008). Both of these require knowledge of the volumetric water content.

The equation for determining soil water content in volume is

$\theta \mathrm{V}=\mathrm{W} 2 / \mathrm{\rho W}) / \mathrm{Vs}$

Where, $\rho \mathrm{w}$ is water density $=1 \mathrm{~g} / \mathrm{cm}^{3}, \mathrm{~W} 2=$ weight of soil water and vs. is Soil sample Volume.

Potato requires well drained soil and good aerated root environment for healthy development of large size tubers. Optimum soil moisture depletion for potato production was $25 \%$ (Doorenbos and Pruitt, 1977). The same source also implies irrigation at frequency of 7-10 days and schedule based on this does not allow the crop to suffer from any water stress; when it corresponds to irrigation at available soil moisture depletion (ASMD) of 20-30 per cent or irrigation at soil moisture tension of 0.3 bars, measured at $15-20 \mathrm{~cm}$ depth.

It is also possible to schedule irrigation applications using root zone water balance approaches (Evans et al., 1996), which apply the Checkbook or budgeting approach to account for all inputs and withdrawals of water from the soil (Jones, 2004). Under favorable conditions, irrigators tend to over irrigate, believing 
that applying more water will result in increased crop yields. But, over irrigation can reduce yields because the excess soil moisture often results in plant disease, nutrient leaching, and reduced pesticide effectiveness. In addition, water and energy are wasted. The amount of water irrigated can often be reduced without reducing yield. Studies have shown that irrigation scheduling using water balance methods can save 15 to $35 \%$ of the water irrigated without reducing yield (Evans et al., 1996). Maximum yield does not equate to maximum profit usually. The optimum economic yield is less than the maximum potential yield. Irrigation scheduling methods aimed at achieving maximum yield that maximizes profit and optimizes water and other resource use should be considered for good economic return from production.

\section{Soil water balance}

Evapotranspiration can also be determined by measuring the various components of the soil water balance. The method consists of assessing the incoming and outgoing water flux into the crop root zone over some time period (Samuel et al., 2009). Irrigation (I) and rainfall (P) add water to the root zone. Part of I and $\mathrm{P}$ might be lost by surface runoff (RO) and by deep percolation (DP) that will eventually recharge the water table. Water might also be transported upward by capillary rise (CR) from a shallow water table towards the root zone or even transferred horizontally by subsurface flow in $\left(\mathrm{SF}_{\text {in }}\right)$ or out $\left(\mathrm{SF}_{\text {out }}\right)$ of the root zone in actual field but in greenhouse especially when the tubers are planted in pots, there is no vertical or horizontal water fraction movement from water table or soil moisture reservoir except leakages which can be managed well to become zero through decreasing irrigation interval and amount of water applied ones. There is no rain also as the experiment is conducted in greenhouse. According to Samuel et al. (2009) in many situations, except under conditions with large slopes, $\mathrm{SF}_{\text {in }}$ and $\mathrm{SF}_{\text {out }}$ are minor and can be ignored. Soil evaporation and crop transpiration are the main water depletion from the root zone. If all fluxes are known and only evapo-transpiration (ET) can be assessed, it can be deduced from the change in soil water content $(\Delta S)$ over the time period (Equation 5$)$ :

\section{$E T C=I+P-R O-D P+C R \pm \Delta S F \pm \Delta S$ for Actual field}

Where, ETC is Evapotranspiration, I is irrigation water, $\mathrm{P}$ is rain fall, $\mathrm{RO}=$ surface runoff, $\mathrm{DP}=$ Deep percolation, $\mathrm{CR}=$ water raised upward by capillary movement, $\Delta \mathrm{SF}=$ Difference of water moved by surface flow in and out of the root zone and $\Delta S=$ Change in soil water content. Generally, the soil water balance equation used in greenhouse container grown crops is:

$E T C=I-D P \pm \Delta S$

Precipitation and other parameters are negligible or zero, but $\Delta S$ (Change in soil water) is obtained either from soil sample or calibrated tensiometer soil moisture value. The limitation of this method is some parameters such as subsurface flow, deep percolation and capillary rise from a water table are difficult to assess in actual field and short time periods cannot be considered. The soil water balance method can usually give ET estimates over long time periods of the order of week-long or ten-day periods.

\section{Nitrogen use efficiency}

Nitrogen use efficiency (NUE) is a multifaceted fact that depends on many internal and external factors. It depends on soil nitrogen availability, its uptake and assimilation, photosynthetic carbon and reluctant supply, carbon-nitrogen flux, nitrate signaling and regulation by light and hormones (Ravi et al., 2008). Nitrogen use efficiency can be computed as taken up nitrogen and/or utilized portion of nitrogen. According to Moll et al. (1982) NUE is also defined as the amount of $N$ taken up by the crop per unit of $\mathrm{N}$ available to the crop, while $\mathrm{N}$ utilization efficiency is the tuber yield per unit of $\mathrm{N}$ uptake by the crop. NUE can also be expressed based on apparent nitrogen recovery using physiological and agronomic parameters (Ravi et al., 2008). Agronomic efficiency is an integrative index of total economic outputs relative to the available soil $\mathrm{N}$ (native and applied) and apparent nitrogen recovery is related to the efficiency of $\mathrm{N}$ uptake while Physiological NUE deals with $\mathrm{N}$ utilization to produce tubers or total plant dry matter and it is directly related to nitrogen utilization efficiency. The most suitable way to estimate NUE depends on the crop, its harvest product and the processes involved in it. According to Battilani et al. (2008) field experiments conducted to assess the nitrogen use efficiency (NUE) of two fertigation treatments (Static and Dynamic) in comparison with a Non-Irrigated/Non-Fertilized (NINF) and an Irrigated/Non-Fertilized (INF) control, expressed as marketable DM yield per $\mathrm{kg}$ available $\mathrm{N}$, is 229.0, 188.2, 166.2 and $173.5 \mathrm{~kg} \mathrm{~kg}^{-1} \mathrm{~N}$ for NINF, INF, Static and Dynamic treatments, respectively.

\section{Utilization efficiency}

All absorbed nitrogen is not involved in producing tuber yield. Some part portioned into formation of above ground biomass the other part below ground biomass. It is measured by the ratio of tuber weight to total plant nitrogen (Moll et al., 1982). According to Battilani et al. (2008) the nitrogen utilization efficiency of Dynamic, Static, NINF and INF in fertigation treatments are 80.6, 77.2, 89.5 and 80.6 kg of total DM per kg of nitrogen uptake, respectively at potato senescence stage. There is variation between different cultivars of the same species, and even more, between crops of different species in nitrogen utilization efficiency. It is this type of response which determines the productivity of crops. There are varietal differences of traditional and improved rice varieties in nitrogen response and NE which are mainly due to the differences in their nitrogen uptake and leaf morphology (Taraka et al., 1964). There are higher NE of potato and sugar beet compared to other crops, as result of their longer period of sink activity (Tanaka et al., 1984). Thus, the factors affecting NE are mostly genetic, although environ- 
ment and the interaction between the genetic character of the variety and the environment, are also important. The growth of the crop is closely affected by these factors, resulting in different patterns of growth. As the pattern of nitrogen uptake during growth is the main factor which can be manipulated to affect the growth pattern, the timing of nitrogen applications improves the absorption efficiency by controlling uptake stage. The ability of absorbed nitrogen to produce grain or straw varies according to the growth stage at which the nitrogen is absorbed (Ishizuka, 1980). The nitrogen absorbed at different stage of growth affects the harvest index of nitrogen and the nitrogen concentration of the harvest organ (Tanaka et al., 1984). But there is little information about time of application that resulted into optimum utilization of nitrogen.

\section{Nitrogen uptake efficiency}

Nitrogen up take is a yield determining parameter that indicates the amount of nitrogen absorbed by the plant root. It is a secondary data obtained from total plant analysis for nitrogen content in laboratory. This nitrogen up take is used for calculating nitrogen uptake efficiency which computed by dividing total plant nitrogen to the total nitrogen supplied or rate of nitrogen applied (Moll et al., 1982). According to Battilani et al. (2008) there were different values of nitrogen use efficiencies of potato at different fertigation treatments. The absorption/ uptake efficiency is varying with crop type, soil conditions, the method and time of application (Lian, 1991). In relation with dependence of absorption efficiency to time of application (Dong et al., 2010) results indicated that highest rate of $15 \mathrm{~N}$ absorption occurred during the first 2 days after application, then decreased to $0.03 \mathrm{~g} \mathrm{~m}^{-2} \mathrm{day}^{-1}$ by Day 4 .On the other hand, they also suggested that at twenty days after foliar urea application, $63.6 \%$ of absorbed $15 \mathrm{~N}$ had been exported from leaves.

Different crops or different varieties of crops absorption of nitrogen are different due to variation in rooting ability and physiological activity requirement of nitrogen. In many cases, ample amounts of fertilizer $\mathrm{N}$, which are more than the crop requirement, are applied in the field which increases the cost of production. Different varieties of crops may also be cropped receiving the same amount of nitrogen fertilizer which is true in potato production in Ethiopia. In such cases, due to lack of knowledge of how efficient the variety can use, there may be shortage or excessiveness of the applied fertilizer that affect the yield. Understanding the up take efficiency, it is also possible to select most profitable variety as more efficient variety can be produced with lesser cost of production related to nitrogen fertilizer (Powell et al., 2010). So it is better to calculate varietal nitrogen efficiency for more profitable production choosing more efficient variety in absorption as well as utilization. Key indicators of nitrogen use efficiency include the following:

$$
\text { Absorption efficiency/uptake }=\frac{\text { Total plant nitrogen }}{\text { Soil nitrogen }+ \text { applied }}
$$

Utilization efficiency $=\frac{\text { Tuber weight or biomass }}{\text { Total plant nitrogen }}$

Agronomic efficiency $=\frac{\text { Integrative index of total economic outputs }}{\text { Soil N (native and applied) }}$

Physiological NUE $=\frac{\text { Produced tubers or total plant dry matter weight }}{\text { N utilized }}$

NUE is calculated for identification of which variety is most efficient to estimate ability to give reasonable yield under marginal nitrogen content of soil. It helps also for declining cost of production to improve farm profit and to reduce environmental pollution (Powell et al., 2010).

\section{FACTORS AFFECTING TUBER YIELD AND BIOMASS}

Effect of nitrogen on yield and yield components of potato Nitrogen is one of the major plant nutrients affecting yield and yield components of potato. According to Zelalem et al. (2009) N and $\mathrm{P}$ application significantly increased aboveground and underground biomass yields of potato. They indicated that application of $207 \mathrm{~kg} \mathrm{~N} / \mathrm{ha}$ increased aboveground biomass yield by $224.5 \%$ while application of $60 \mathrm{~kg} P /$ ha increased $32 \%$ yield compared to the control. A significant increase in canopy dry matter yield in response to $\mathrm{N}$ fertilization is reported by Millard and Marshall (1986). They also mentioned marketable yield increase by $176 \%$ and total tuber yield by $119 \%$ as a result of application of 0 to $207 \mathrm{~kg} \mathrm{~N} / \mathrm{ha}$. N fertilization increased potato plant height with differential response between varieties (Yibekal, 1998). N plays a significant role in production of stem and axillary branches (Moorby and Morris, 1967). Continuous supply of $\mathrm{N}$ to potato crop promote shoot and root growth while reducing tuberization (Gunasena and Harris, 1969).

Nitrogen and $\mathrm{P}$ fertilization can improve both the marketable and total tuber yield of potato due to increased radiation interception during the first part of the season and lower rates of decline in photosynthetic efficiency of the canopy during the later part (Millard and Marshall, 1986). Kotsyuk (1995) also revealed leaf area and duration of tuber bulking increase because of fertization. $\mathrm{N}$ fertilizer affects yield by its effect on average tuber number, the average tuber weight and the establishment (Wilcox and Hoff, 1970). Timm and Flocker (1966) indicated optimum tuber yield at application of $204 \mathrm{~kg} / \mathrm{ha} \mathrm{N}$ fertilizer and yield reduction is noted when applied above this rate. Tuber number increase in response to $\mathrm{N}$ fertilization can be attributed to an increase in stolon number through nitrogen effect on Gibberellins biosynthesis in the potato plant (Zelalemet al., 2009). The involvement of gibberellins in regulating stolon number through stolon initiation is described by Kumar and Wareing (1972). N effect on tuber formation in potato is by influencing the activity and phytohormone balance in the plant, especially, on the levels of gibberellic and abscissic acids as well as cytokinins (Amzallag et al., 1992). 


\section{Climate of the area}

Air temperature, solar radiation and photoperiod:-Among the climatic condition temperature, solar radiation and photoperiod are the most important potato growth and development determinants. The review by Haverkort (1990) points out that potato is best adapted to cool climates such as tropical highlands with mean daily temperatures between 15 and $18^{\circ} \mathrm{C}$ as encountered in its center of origin. Higher temperatures favor foliar development and retard tuberization. In addition, heat stress leads to a higher number of smaller tubers per plant; lower tuber specific gravity with reduced dry matter content, and usually to a paler skin color of the tubers. Temmerman et al. (2002) examined the effect of latitude, seasonal mean air temperature (ranging from 13.8 to $19.9^{\circ} \mathrm{C}$ ), global solar radiation (ranging from 12.0 to 21.3

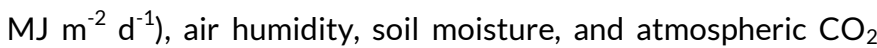
concentrations on tuber yield in European experiments. Ignoring $\mathrm{CO}_{2}$ enrichment, the yield of potato (cv. 'Bintje') increased from south to north Europe. Marketable tuber yields increased at higher latitudes. Climatic conditions, not only affected by the latitude but also by altitude, influence potato plant growth and development. Moreno (1985) found that plants grown at low (coastal) altitudes have low yield of tubers per plant as compared with those grown in the Andean highlands. Gawronska and Dwelle (1989) studied the effect of high light levels (maxima between 500 and $1200 \mathrm{E} \mathrm{m}^{-2} \mathrm{~s}^{-1}$ ) and shaded low light levels (approximately one-quarter of the high light) on potato plant growth, biomass accumulation and its distribution. They observed that plants under low light do not produce auxiliary shoots. Tubers of plants under low light were very small and irregular in shape. The most evident plant response to low light was greater stem elongation as well as a reduction in total biomass accumulation and in tuber weights. The reduction in total biomass under low light was 34 to $45 \%$. Reduction in tuber dry weights under low light ranged from 39 to $57 \%$, depending on the growth stage and harvest time. In addition, at all growth stages, the percentage of biomass partitioned to the tubers was higher under high light than under low light conditions.

\section{Soil temperature}

Soil temperature also affects the various activities of growing potato. The rate of development of sprouts from planted seed pieces depends on soil temperature. Very little sprout elongation occurs at $6^{\circ} \mathrm{C}$. Elongation is slow at $9^{\circ} \mathrm{C}$ and is maximized at about $18^{\circ} \mathrm{C}$. The time between planting and emergence depends on soil temperature. Phytotron and field experiments carried out by Sale (1979) showed that emergence was linearly related to mean soil temperature and relatively independent of diurnal fluctuations up to an optimum of $22-24^{\circ} \mathrm{C}$. Up to this optimum emergence can be considered as a degree-day requirement calculated either from soil temperature at tuber depth or air temperature. At temperatures above the optimum, emergence was inhibited. Sattelmacher et al. (1990) studied the effect of $20^{\circ} \mathrm{C}$ and $30^{\circ} \mathrm{C}$ root-zone temperatures on root growth and root morphology of six potato clones. Significant genotypic differences in the responses of potato roots to $30^{\circ} \mathrm{C}$ were observed, indicating the potential for selecting heat tolerant potato clones. In both heat tolerant and heat sensitive clones, the size of the root system was reduced by a $30^{\circ} \mathrm{C}$ root-zone temperature explained by a reduction in the cell division followed by cessation of root elongation. Tuberization stimulus favors both tuber initiation and tuber enlargement. Through artificially prolonged exposure to short days and cool temperatures, it is possible to attain such a high level of stimulus that induction is irreversible, even if potato plants are subsequently exposed to long days for weeks or months. The optimum soil temperature for initiating tubers ranges from 16 to $19^{\circ} \mathrm{C}$ (Western Potato Council, 2003).

\section{Atmospheric humidity and wind}

There are very few recent studies dealing with the direct effects of relative humidity $(\mathrm{RH})$ on potato growth, tuber yield and grade. Most of the contributions related to the influence of $\mathrm{RH}$ on potato refer to potato storage where $\mathrm{RH}$ is an important factor in tuber weight loss and the occurrence and severity of diseases and pests. The same scarcity of research exists with regard to the wind regimes at a particular location as an agro meteorological factor affecting potato production systems. Wheeler et al. (1989) studied the effect of two RH levels, 50\% and $85 \%$, on the physiological responses of three cultivars of potato (Russet Burbank, Norland, and Denali) in controlledenvironment rooms under continuous light intensity at $20^{\circ} \mathrm{C}$. No significant differences in total plant dry weight were measured between the atmospheric humidity treatments, but plants grown under $85 \% \mathrm{RH}$ produced the higher tuber yields. Leaf areas were greater under $50 \% \mathrm{RH}$ and leaves tended to be larger and darker green under drier than at more humid atmospheric conditions. The elevated humidity appeared to shift the allocation pattern of photosynthesis to favor allocation to the tubers over leaves and stems. Gordon et al. (1999) estimated sap flow from solar radiation and vapor pressure deficit data for three field-grown potato cultivars ('Atlantic', 'Monona' and 'Norchip') at Nova Scotia, Canada, under non-limiting soil water conditions. Sap flow rates for all cultivars were closely linked with solar radiation under conditions where soil water was not limiting. The vapor pressure deficit (VPD), a function of relative humidity and air temperature, had less effect on sap flow, although the magnitude of the VPD during the growing season was generally $2 \mathrm{kPa}$.

All cultivars maintained actual daily transpiration near the potential energy limiting rate under well-watered conditions. When the soil was drier (percent available soil water $30 \%$ ), Monona potato plants had a much more rapid decline in transpiration than the other two cultivars. Another physiological parameter closely related to yield is water use efficiency. According to Bowen (2003) the cool humid conditions favored growth and promoted a more efficient use of irrigation water in coastal Peru condition when grown during winter time. During winter, less soil water evaporation caused by smaller VPD enhanced water use efficiency when compared with that observed during the summer. Sinclair et al. (1984) also showed 
that generally more humid environments provide greater water use efficiency because of a lower VPD. Stomatal resistance governs photosynthesis and transpiration. Two major feedback loops are reported by Raschke (1979) as the direct controllers of stomatal resistance. The first involves photosynthesis where a reduction in intercellular carbon dioxide $\left(\mathrm{CO}_{2}\right)$ occurs as the photosynthetically active radiation increases, the stomata open and stomatal resistance decreases. The second involves an increase in stomatal resistance whenever leaf water potential reaches a critical threshold as a result of transpiration intensity (Raschke, 1979). Wind also affects transpiration rates and, therefore, photosynthetic activity and crop yield. At sites where winds are frequently strong throughout the year, increased stomatal resistance can cause reduction in potato yield (Sun and Dickinson, 1997; Pavlista, 2002).

Effect of irrigation regimes and methods on tuber yield and yield components

Irrigation water amount and quality is a factor to be considered for better yields. According to the finding of Faberio et al. (2001) $597 \mathrm{~mm}$ irrigation water required to reach maximum tuber yield of $45.18 \mathrm{t} / \mathrm{ha}$. Onder et al. (2005) suggested that surface and subsurface drip irrigation methods did not significantly affect tuber yield. Increased tuber yield with irrigation applications was noted in Shock et al. (1998) and Yuan et al. (2003) reported. Tuber dry matter yield increased with increasing water supply from $60-100 \%$ full irrigation but it decline at $120 \%$ of full irrigation (Darwish et al., 2006). Onder et al. (2005) mentioned that irrigation levels significantly affected all yield parameters in two consecutive years and yield for 66 and 100\% irrigation regimes were significantly superior to $33 \%$ and non-irrigated treatments. Also, Nagaz et al. (2007) indicated similar findings. Tuber fresh and dry weight from first- three harvests for full irrigation tend to be higher than partial root zone drying but at fourth harvest partial root zone drying have got highest amounts (Shahnazari et al., 2007).

Erdem et al. (2006) narrated that effect of irrigation regimes in two consecutive years did not significantly affect tuber weight but tuber yield only in 2005 was significantly affected by irrigation regimes. On the other hand, Darwish et al. (2006) stated lowering of deficit irrigation the tuber dry matter production and the average weight of the commercial tuber. In addition, Onder et al. (2005) reported the highest tuber means weight from irrigation treatment of 66 and 100\% of full irrigation. Nagaz et al. (2007) explained reduction in tuber number and weight as a consequence of water supply shortage during tubers initiation and development. Significantly the highest plant yield for 66 and 100\% full irrigation over 33\% and non-irrigated treatments was indicated (Onder et al., 2005). Yuan et al. (2003) reported that significantly lower biomass for use of 0.25 and 0.50 Evapotranspiration compared to $0.75,1.00$ and 1.25 times of evapo-transpiration. Increased water stress decreased total dry matter yield (Kashyap and Panda, 2003). Darwish et al. (2006) found out that increased water supply increased the harvest index with the highest amount at $100 \%$ of irrigation.
Similar result was reported by Shahnazari et al. (2007). At In sandy loam soil grown potato at temperature of $26^{\circ} \mathrm{C}$ irrigation regimes of 100,80 and $60 \%$ produced a WUE of 0.0098 , 0.00754 and $0.00536 \mathrm{~g}$ wet tuber yield per one $\mathrm{mm}$ irrigation in one meter square, respectively (Steyn et al., 2007).

\section{Effect of irrigation and nitrogen interaction on potato yield} Land and water is major constraints to the production of food required to meet the quantitative and qualitative world's demand with greatly increasing population. Therefore, it is critical to optimize agricultural water use. This agricultural water use optimization requires both maximizing productivity per unit of land and maximizing productivity per unit of water consumed (Stefania et al., 2011). To maximize WUE, it is necessary to conserve water and promote maximal crop productivity which intern requires combined works involving minimization of water losses through seepage, runoff, evaporation, and evapotranspiration by weeds; and planting well adapted high-yielding crops/ cultivars with optimum managements. Improving cropping environment by proper management like harvesting time, tillage, fertilization, and pest control also contribute to enhancement of crop growth and productivity. The water use efficiency not only depends on the crop yield but also depends on water application level (Kumar et al., 2007). When the water application level increased beyond the requirement of the crop, the water use efficiency decreases. Studies found a poor correlation (R2 = 0.24 ) between the WUE and water application level (Kireger and Blake, 1994; Speer et al., 2008). Irrigation regime and method significantly influenced water and nitrogen use efficiency (Lehrsch et al., 2000).

Nitrogen rates cause change on water use efficiency by potentially affecting biomass, evaporations, transpirations and $\mathrm{HI}$ through primarily influencing photosynthesis. There is close relationships between water and nutrient availabilities (Wu et al., 2009). Response of all major crop species to nitrogen supply in biomass per unit transpiration was indicated in Bruick (2008). Cooper et al. (1987) demonstrated the increment of WUE with nitrogen and phosphorous fertilization in low-fertile soils of west Asia and North Africa. On the other hand, significantly lower WUE under lowest level of nitrogen supply was indicated in Brücket al. (2001). According to Kelm et al. (1999-2000) fertilized condition increased WUE compared to not fertilized condition. Hence, adequate nitrogen supply is therefore, critical for high yield per unit evapotranspiration or better improvement of water use efficiency.

In same manner with these, nitrogen application rates affect nitrogen use efficiency. Increasing nitrogen application from 80 $\mathrm{kg} / \mathrm{ha}-200 \mathrm{~kg} / \mathrm{ha}$ reduced nitrogen use efficiency (Shahzad et al., 2010). This indicates that the increment of nitrogen fertilizer increase NUE up to the maximum yield potential (Hartemink et al., 2000). In relation with this, Darwish et al. (2006) found that decreasing $\mathrm{N}$ application to $125 \mathrm{~kg} / \mathrm{ha}$, from 250,375 or $500 \mathrm{~kg}$ $\mathrm{N} /$ ha, resulted in significantly higher $\mathrm{N}$ recovery or nitrogen up take efficiency. Similarly, according to Shahzad et al. (2010) highest nitrogen levels produced lowest physiological nitrogen 
use efficiency. Increasing water use efficiency indicated with increasing nitrogen supply to the optimum level (Caviglia and Sadras, 2001). So, it is considerable to find the common effect of irrigation and nitrogen rates on potato yield, water and nitrogen use efficiencies for better farm return. Nitrogen and irrigation have important interactive effects on $\mathrm{N}$ and water use efficiency, potato yield and quality, as well as, $\mathrm{N}$ and water losses to the environment. Meyer and Marcum (1998) found out maximum tuber yields from $1.1-1.2 \mathrm{ETC}$ and $0-56 \mathrm{~kg} \mathrm{ha}^{-1} \mathrm{~N}$ in combination 1992, while 1.1-1.3 ETC and 168-224 $\mathrm{kg} \mathrm{ha}^{-1} \mathrm{~N}$ maximized yield in 1993. Feibert et al. (1998) reexamined nitrogen fertilizer rates and timing for four potato cultivars in the Treasure Valley of Oregon throughout 3 consecutive years on silt loam soil. They concluded that with careful irrigation scheduling (initiated when the SWT at $0.2 \mathrm{~m}$ depth reached $60 \mathrm{kPa}$ and with amounts corresponding to accumulated ETC) less nitrogen fertilizer was required to optimize yield than usual recommendations. Optimal potato petiole $\mathrm{N}$ levels through the growing season were identified for Russet Burbank (Jones and Painter, 1974).

\section{Conclusion}

It is concluded that best potato growing condition available in Ethiopia was not exploited well compared to other countries. Poor resource and crop management was found the most important problems of production and productivity. There was big gap in optimum nitrogen rate utilization, limitation of irrigation water utilization, nitrogen and water use efficiency consideration in agronomic work of the country. In the process of resource use optimization, crop type to be grown and variety have also a remarkable contribution. On the last the nitrogen rate, irrigation regime and use efficiency of nitrogen and water were interrelated to each other and variety development program should consider these parameters to gather with the yield and yield component of the potato for sustainable production with maintained safe environment sufficient benefit.

Open Access: This is an open access article distributed under the terms of the Creative Commons Attribution 4.0 License, which permits unrestricted use, distribution, and reproduction in any medium, provided the original author(s) if the sources are credited.

\section{REFERENCES}

Amzallag, G.N., Lerner, H.R. and Poljakoff-Mayber, A. (1992). Interaction between mineral nutrients, cytokinin and gibberellic acid during growth of sorghum at high $\mathrm{NaCl}$ salinity. Journal of Experimental Botany, 43(1): 81-87, https://doi.org/10.1093/jxb/43.1.81

Ayers, R.S. and Westcot, D.W. (1985). Water quality for agriculture (Vol. 29). Rome: Food and Agriculture Organization of the United Nations.

Battilani, A., Dalla Costa, L. and Lovatti, L. (2004). Water and nitrogen use efficiency of potato in sub-humid area. Acta Horticulturae, 664: 63-70, https://doi.org/10.17660/ActaHortic.2004.664.5

Battilani, A., Plauborg, F.L., Hansen, S., Dolezal, F., Mazurczyk, W., Bizik, J. and Coutinho, J. (2008). Nitrogen uptake and nitrogen use efficiency of fertigated potato. Retrieved from http://home.elka.pw.edu.pl/ wmazurcz/wm/art/ Nitrogen.pdf
Bereke, T.T. (1988). Potato research and future improvement prospects in Ethiopia: Proceedings of the 19th National Crop Improvement. Conference held in Addis Ababa, Ethiopia, pp. 301-310.

Bergaten, R.V., Daisog, H.S., Bolatete Jr., D.M., Belmonte Jr., D.V., Esquibel, C.B., Pardales, A.D., Mariscal, A.M., Sebidos, R.F., Banoc, D.M. and Subere, J.Q. (2003). Genotypic variation in sweet potato (Ipomoea batatas L.) in response to water deficit during plant establishment stage. Philippine Journal of Crop Science, (Philippines), Retrieved from http://agris.fao.org/agris-search/ search.do?recordID=PH2003001160

Biemond, H., and Vos, J. (1992). Effects of nitrogen on the development and growth of the potato plant. 2. The partitioning of dry matter, nitrogen and $\begin{array}{llll}\text { nitrate. Annals } & \text { Botany, }\end{array}$ https://doi.org/10.1093/oxfordjournals.aob.a088437

Bishop, J.C. and Grimes, D.W. (1971-74). Precision tillage effects on potato root and tuber production American Journal of Potato Research. Contribution from the departments of Vegetable Crops and Land, Air and Water Resources: Water Science and Engineering Section, University of California, Davis 95616.55 (2): 65-71.

BMPNU (2008). Best Management Practices for Nitrogen Use: Irrigated Potatoes.2008.

Bowen, W.T. (2003). Water productivity and potato cultivation. pp. 229-238.

Brück, H., Jureit, C., Hermann, M., Schulz, A. and Sattelmacher, B. (2001). Effects of water and nitrogen supply on water use efficiency and carbon isotope discrimination in edible canna (Canna edulis Ker-Gawler). Plant Biology, 3: 326-334, https://doi.org/10.1055/s-2001-16450

Brück, H., Sattelmacher, B., Jureit, C., Hermann, M. and Schulz, A. (2008). Effects of water and nitrogen supply on water use efficiency and carbon isotope discrimination in edible canna (Canna edulis Ker-Gawler). Journal of Plant Nutrition and Soil Science, 171: 210, https://doi.org/10.1055/s-2001-16450

Caviglia, O.P. and V.O. Sadras, (2001). Effect of nitrogen supply on crop conductance, water- and radiation-use efficiency of wheat. Field Crops Research, 69 (3): 259-266, https://doi.org/10.1016/S0378-4290(00)00149-0

Chowdhury, S.R., Aatony, E., Singh, R., Thakur, A.K. and Verma, H.N. (2001). Leaf area development and its relationship with tuber yield in sweet potato under different irrigation regimes. Orissa Journal of Horticulture, 29: 20-23.

Cooper, P.J.M. and Gregory, P.J. (1987). Soil water management in the rain-fed farming systems of the Mediterranean region. Soil Use and Management, 3: 57 -62, https://doi.org/10.1111/j.1475-2743.1987.tb00711.x

CSA, Central Statistical Agency (2001). Report on Area and Production of Crops. Unpublished Agricultural Index Survey Report, Addis Ababa, Ethiopia.

CSA, Central Statistical Agency (2015). Report on Area and Production of Crops. Unpublished Agricultural Index Survey Report, Addis Ababa, Ethiopia.

Curwen, D. (1993). Water management. In Rowe, R.C. (ed.) Potato Health Management. The American Psychopathological Society, ASP Press, Wooster, Ohio. 26. pp. 67-75.

Darwish, T.M., Atallah, T.W., Hajhasan, S. and Haidar, A. (2006). Nitrogen and water use efficiency of fertigated processing potato. Agriculture Water Management, 85(1-2): 95-104, https://doi.org/10.1016/j.agwat.2006.03.012

Davenport, J.R., Milburn, P.H., Rosen, C.J. and Thornton, R.E. (2005). Environmental impacts of potato nutrient management. American Journal of Potato Research, 82: 321-328, https://doi.org/10.1007/BF02871962

Deblonde, P.M.K., Haverkort, A.J. and Ledent, J.F. (1999). Responses of early and late potato cultivars to moderate drought conditions. Agronomic parameters and carbon isotope discrimination. European Journal of Agronomy, 11: 91-105, https://doi.org/10.1016/S1161-0301(99)00019-2

Dong, C., Sun, S. and Taylor, G.A. (2010). Numerical modeling of contaminant transport in fractured porous media using mixed finite element and finite volume methods. Retrieved from https://tigerprints.clemson.edu/all_theses

Doorenbos, J. and Pruitt, W.O. (1977). Crop water requirements, irrigation and drainage paper 24. Food and Agricultural Organization of the United Nations Rome, Italy.

Doorenbos, J. and Pruitt, W.O. (1977). Guidelines for predicting crop water requirements. FAO Irrigation and Drainage Paper No. 24. Food and Agriculture Organization of the United Nations.

Doorenbos, J. and Kassam, A.H. (1979). Yield response to water. FAO Irrigation and Drainage Paper, No. 33. FAO, Rome, pp.193.

Eldredge, E.P., Shock, C.C. and Stieber, T.D. (1992). Plot sprinklers for irrigation research. Agronomy Journal, 84: 1081-1984, https://doi.org/10.2134/agronj1992.00021962008400060034x

Eldredge, E.P., Holmes, Z.A., Mosley, A.R., Shock, C.C. and Stieber, T.D. (1996). Effects of transitory water stress on potato tuber stem-end reducing sugar 
and fry color. American Potato Journal, 73: 517-530, https://doi.org/10.1007/BF02851697

Erdem, T., Orta, A.H., Erdem, Y. and Okorsoy, H. (2005). Crop water stress index for potato under furrow and drip irrigation systems. Potato Research, 48: 4958, https://doi.org/10.1007/BF02733681

Erdem, T., Erdem, Y., Orta, H. and Okursoy, H. (2006). Water-yield relationships of potato under different irrigation methods and regimes. Scientia Agricola, 63: 226231, http://dx.doi.org/10.1590/S0103-90162006000300003

Epstein, E., and Grant, W.J. (1973). Water stress relations of the potato plant under field conditions. Agronomy Journal, 65: 400-404, http://dx.doi.org/10.2134/agronj1973.00021962006500030015x

Evans, R.G., Han, S., Kroegen, M.W. and Schneider, S.M. (1996). Precision center pivot irrigation for efficient use of water and nitrogen. P.75-84. In P.C. Robert et al. (ed.) $3^{\text {rd }}$ International Conference on Precision Agriculture, Minneapolis, MN. 23-26 June, 1996. ASA Madison, WI.

Fabeiro, C., Martin de Santa Olalla, F. and de Juan, J.A. (2001). Yield and size of deficit irrigated potatoes. Agricultural Water Management, 48(3): 255-266, https://doi.org/10.1016/S0378-3774(00)00129-3

FAO (2002). Onion water management. The AGLW Water Management Group, Land and Water Development Division Rome, Italy, http://www.fao.org/

FAO (1998). FAOSTAT Agricultural data. Provisional 2003 Production and Production Indices Data. Crop primary, Retrieved from http://apps.fao.org/d efault.jsp

FAO (2006). FAOSTAT agriculture. Rome, Retrieved from http://faostat.fao.org/faostat/collections?subset=agriculture

FAO (2008). Agriculture Rome, Available in http://faostat.fao.org/ faostat/ collections? Subset=agriculture. Accessed on 1 April 2008.

Feibert, E.B.G., Shock, C.C. and Saunders, L.D. (1998). Nitrogen fertilizer requirements of potatoes using carefully scheduled sprinkler irrigation. HortScience, 32: 262-265.

Ferreira, T.C. and Carr, M.K.V. (2002). Responses of potatoes (Solanum tuberosum L.) to irrigation and nitrogen in a hot and dry climate. Field Crops Research, 78: 51-64.

Gawronska, H. and Dwelle, R.B. (1989). Partitioning of photo assimilates by potato plants (Solanum tuberosum L.) as influenced by irradiance partitioning patterns in cultivar Russet Burbank grown under high and low irradiance. American Potato Journal, 66: 201-213.

Gebreegziabher Lemma Hagos (2005). The role of Household Ponds on the expansion of Home gardens in Igray, Ethiopia M.Sc. Thesis.

Geremew, E.B. (2008). Modelling the soil water balance to improve irrigation management of traditional irrigation schemes in Ethiopia. Ph.D. Thesis, University of Pretoria.

Getu, B. (1998). Yield, quality and nitrogen uptake of potato (Solanum tuberosum L.) as influenced by rate and time of nitrogen application. M.Sc. Thesis, Alemaya University, Ethiopia.

Gordon, R., Brown, D.M., Madani, A. and Dixon, M.A. (1999). An assessment of potato sap flow as affected by soil water status, solar radiation and vapour pressure deficit. Canadian Journal of Soil Science, 79: 245-253.

Gunasena, H.P.M. and Harris, P.M. (1969). The effects of CCC and nitrogen on the growth and yield of the second early potato variety, Craig's Royal. Journal of Agriculture Science, 73: 245-259

Hane, D.C. and Pumphrey, F.V. (1984). Yield-evapotranspiration relationships and seasonal crop coefficients for frequently irrigated potatoes. American Potato Journal, 61: 661-668.

Hartemink, A.E., Johnston, M., O'Sullivan, J.N. and Poloma, S. (2000). Nitrogen use efficiency of taro and sweet potato in the humid lowlands of Papua New Guinea. Agriculture, Ecosystem and Environment, 79: 271-280.

Hassan, A.A., Sarkar, A.A., Ali, M.H. and Karim, N.N. (2002). Effect of deficit irrigation at different growth stages on the yield of potato. Pakistan Journal of Biological Science, 5: 128-134.

Haverkort, A.J. (1990). Ecology of potato cropping systems in relation to latitude and altitude. Agricultural System, 32(3): 251-272, https://doi.org/10.1016/0308-521X(90)90004-A

Hegney, M.A. and Hoffman, H.P. (1997). Potato irrigation development of irrigation scheduling guidelines. Final Report, Horticultural Research and Development Corporation Project NP 6. Agriculture Western Australia, pp. 114.

Hignett, C. and Evett, S. (2008). Field Estimation of Soil Water Content. A Practical Guide to Methods, Instrumentation and Sensor Technology. Direct and Surrogate Measures of Soil Water Content.

Honisch, M., Hellmeier, C. and Weiss, K. (2002). Response of surface and subsurface water quality to land use changes. Geoderma, 105(3-4): 277-298,
https://doi.org/10.1016/S0016-7061(01)00108-2

Horton, D. (1987). Potato production, marketing and programs for developing countries. West view Press, London.

IAR, Institute of Agricultural Research (2000). HolettaGuenet Research Station Progress Report, Addis Ababa, Ethiopia.

Ishizuka, Y. (1980). The importance of nitrogen for the growth of the rice plant. In: Increasing Nitrogen Efficiency for Rice Cultivation", Y. Ishizuka et al. (Eds.). FFTC Book Series No. 18. Food and Fertilizer Technology Center for the ASPAC Region, Taipei, Taiwan R.O.C., pp. 1-14.

Jensen, M.E., Burman, R.D. and Allen, R.G. (1990). Evapotranspiration and irrigation water requirements. ASCE Manual No 70. ASCE, New York.

Jim Bauder and Linzy Carlson (2010). Water Quality and Irrigation Management. Soil Moisture Monitoring: What does 65\% Depletion mean? The Department of Land Resource and Environmental Management. Available at https://montana.edu

Jones, H.G. (2004). Irrigation scheduling: advantages and pitfalls of plant-based methods. Journal of Experimental Botany, 55: 2427-2436, https://doi.org/10.1093/jxb/erh213

Jones, J.P. and Painter, C.G. (1974). Tissue analysis: A guide to nitrogen fertilization of Idaho Russet Burbank Potatoes. University of Idaho, College of Agriculture, Cooperative Extension Service, Agricultural Experiment Station, Current information series \# 240, June 1974.

Kang, Y., Wang, F.X., Liu, H.J. and Yuan, B.Z. (2004). Potato evapotranspiration and yield under different drip irrigation regimes. Irrigation Science, 23: 133-143, https://doi.org/10.1007/s00271-004-0101-2

Kashyap, P.S. and Panda, P.K. (2001). Evaluation of evapotranspiration estimation methods and development of crop-coefficients for potato crop in a subhumid region. Agriculture Water Management, 50(1): 9-25, https://doi.org/10.1016/S0378-3774(01)00102-0

Kashyap, P.S. and Panda, R.K. (2002). Optimum utilization of surface irrigation water under deficit situations. Proceedings of the international conference on "Sustainable development of water in $21^{\text {st }}$ century" central board of irrigation and power, New Delhi. September 27-29.

Kashyap, P.S. and Panda, R.K. (2003). Effect of irrigation scheduling on potato crop parameters under water stressed conditions. Agriculture Water Management, 59(1): 49-66, https://doi.org/10.1016/S0378-3774(02)00110-5

Kelm, H. Brück, Hermann, M. and Sattelmacher, B. (1999-2000). Plant productivity and water use efficiency of sweet potato (Ipomoea batatas) as affected by nitrogen supply. CIP Program Report 1999-2000.

Kirda, C. (2002). Deficit irrigation scheduling based on plant growth stages showing water stress tolerance. Deficit Irrigation Practices, Water Reports 22. FAO, pp. 3-10.

Kireger, E.K. and Blake, T.J. (1994). Genetic variation in dry matter production, water use efficiency and survival under drought in four Acacia species. Advances in Geoecology, 27: 195-204.

Kiziloglu, F.M., Sahin, U., Tune, T. and Diler, S. (2006).The effect of deficit irrigation on potato evepotranspiration and tuber yield under cool season and semiarid climatic conditions. Journal of Agronomy, 5: 284-288.

Kleinkopf, G.E., Westermann, D.T., and Dwelle, R.B. (1981). Dry matter production and nitrogen utilization by six potato cultivars. Agronomy Journal, 73: 799802, https://eprints.nwisrl.ars.usda.gov/377/1/464.pdf

Kotsyuk, V.I. (1995). Using statistical methods for estimating the effect of fertilizers on potato productivity in the kol'skoi subaritic region. Agrokhinya, 12: 76-88.

Kumar, D. and Wareing, P.F. (1972). Factors controlling stolon development in potato plant. New Phytologist, 71: 639-648, https://doi.org/10.1111/j.1469-8137.1972.tb01274.x

Kumar, S., Imtiyaz, M., Kumar, A. and Singh, R. (2007). Response of onion (Allium cepa L.) to different levels of irrigation water. Agriculture Water Management, 89(1-2): 161-166, https://doi.org/10.1016/j.agwat.2007.01.003

Lahlou, O., Ouattar, S. and Ledent, J.F. (2003).The effect of drought and cultivar on growth parameters, yield and yield components of potato. Agronomie, 23: 257-268, https://doi.org/10.1051/agro:2002089

Lehrsch, G.A., Sojka, R.E. and Westermann, D.T. (2000). Nitrogen placement, row spacing, and furrow irrigation water positioning effects on corn yield. Agronomy Journal, 92(6): 1266-1275, http://citeseerx.ist.psu.edu/viewdoc/ download?doi=10.1.1.627.5640\&rep=rep1\&type=pdf

Levy, D. (1992). Potato in hot climates-could we do more? Proceeding of advanced potato production in the hot climates symposium, 24-28 May 1992, Nahal-OZ, Israel. pp. 3-7.

Lian, S. (1991). Efficiency of nitrogen fertilization on upland crops grown in multiple cropping systems in Taiwan. Department of Agricultural Chemistry 
Taiwan Agricultural Research Institute Wufeng, Taichung 41301, ROC on Taiwan,1991-12-01.

Love, S.L., Novy, R., Corsini, D. L. and Bain, P. (2003). Variety selection and management. Pages 21-47 in: Potato Production Systems. J. C. Stark and S. L. Love, eds. Agric. Commun., Univ. of Idaho, Moscow.

Luisa Dalla Costa, _DelleVedove, G., Gianquinto, G., Giovanardi, R. and Peressotti, A. (1997). Yield, water use efficiency and nitrogen uptake in potato: influence of drought stress. Potato Research, 40 (1): 19-34, https://doi.org/10.1007/BF02407559

Madramootoo, C.A., Wayo, K.A. and Enright, P. (1992). Nutrient losses through tile drains from potato fields. American Society of Agricultural and Biological Engineers, 8: 639-646, https://doi.org/10.13031/2013.26136

Maynard, D.N. and Lorenz, O.A. (1979). Controlled release fertilizers for horticultural crops. Horticultural Reviews, 1:79-140.

Meyer, R.D. and Marcum, D.B. (1998). Potato yield, petiole nitrogen, and soil nitrogen response to water and nitrogen. Agronomy Journal, 90(3): 420-429, https://doi.org/10.2134/agronj1998.00021962009000030017x

Millard, P. and Marshall, B. (1986). Growth, nitrogen up take and portioning in potato (Solanum tuberosum) crop in relation to nitrogen application. Journal of Agriculture (Cambridge), 107: 421-429.

Molden, D. (1997). Accounting for Water use and Productivity, SWIM paper 1. Colombo, Sir lanka: International Irrigation Management Institute.

Moll, R.H., Kamprath, E.J. and Jackson, W.A. (1982). Analysis and interpretation of factors which contribute to efficiency of nitrogen utilization. Agronomy Journal, $\quad$ 74(3): 562-570, https://doi.org/10.2134/agronj1982.00021962007400030037x

Moorby, J. and Morris, D.A. (1967). Inter-stem and inter-tuber competition in potato. European Potato Journal, 10: 189-205, https://doi.org/10.1007/ BF02364428

Moreno, U. (1985). Environmental effects on growth and development of potato plants. pp. 481-501. In P.H. Li (ed.) Potato Physiology. Academic Press, Inc. Orlando, FL.

Munoz, F., Mylavarapu, R.S., and Hutchinson, C.M. (2005). Environmentally responsible potato production systems: A review. Journal of Plant Nutrition, 28(8): 1287-1309, https://doi.org/10.1081/PLN-200067434

Nagaz, K., Masmoudi, M.M. and Mechlia, N.B. (2007). Soil salinity and yield of drip irrigated potato under different irrigation regimes with saline water in arid conditions of southern Tunisia. Journal of Agronomy, 6: 324-330, https://doi.org/10.3923/ja.2007.324.330

Ojala, J.C., Stark, J.C. and Kleinkopf, G.E. (1990). Influence of irrigation and nitrogen management on potato yield and quality. American Potato Journal, 67: 29-43, https://doi.org/10.1007/BF02986910

Onder, S., Caliskan, M.E., Onder, D. and Caliskan, S. (2005). Different irrigation methods and water stress effects on potato yield and yield components. Agriculture Water Management, 73(1): 73-86, https://doi.org/10.1016/j.agwat.2004.09.023

Pack, J.E., Hutchinson, C.M. and Simonne, E.H. (2006). Evaluation of controlledrelease fertilizers for northeast Florida chip potato production. Journal of Plant Nutrition, 29(7): 1301-1313, https://doi.org/10.1080/01904160600767633

Panigrahi, B., Panda, S.N. and Raghuwanshi, N.S. (2001). Potato water use and yield under furrow irrigation. Irrigation Science, 20: 155-163, https://doi.org/10.1007/s002710100042

Pankhrust, R. (1964). Notes on history of Ethiopian Agriculture. Ethiopian Observer, 7: 210-240.

Pavlista, A.D. (2002). Environmental effects. Nebraska Potato Eyes, 14: 1-4.

Pereira, A.B. and Shock, C.C. (2006). Development of irrigation best management. 1: 1-20.

Peter, R. Gildemacher, Wachira Kaguongo, Oscar Ortiz, Agajie Tesfaye, Gebremedhin Woldegiorgis, William W. Wagoire, Rogers Kakuhenzire, Peter M. Kinyae, Moses Nyongesa, Paul C. Struik and Cees Leeuwis (2009). Improving potato production in Kenya, Uganda and Ethiopia: Potato Research, 52(2): 173-205, https://doi.org/10.1007/s11540-009-9127-4

Powell, J.M., Gourley, C.J.P., Rotz, C.A. and Weaver, D.M. (2010). Nitrogen use efficiency: A potential performance indicator and policy tool for dairy farms. Environmental Science \& Policy, 13(3): 217-2 https://doi.org/10.1016/j.envsci.2010.03.007

Raine, G. (1999). Causes and effects of stress on farmers: a qualitative study. Health Education Journal, 58(3): 259-270.

Raschke, K. (1979). Movements using turgor mechanisms.In W. Haupt and M.E. Feinleib (eds.) Physiology of Movements, Encyclopedia of Plant Physiology.
Springer-Verlag, Berlin, pp. 383-441.

Pathak, R.R., Ahmad, A., Lochab, S. and Raghuram, N. (2008). Molecular physiology of plant nitrogen use efficiency and biotechnological options for its enhancement. Current Science, 1394-1403.

Reddy, A.R., Chaitanya, K.V. and Vivekanandan, M. (2004). Drought-induced responses of photosynthesis and antioxidant metabolism in higher plants. Journal of Plant Physiology, 161(11): 1189-1202, https://doi.org/10.1016/j.jplph.2004.01.013

Shae, J.B., Steele, D.D. and Gregor, B.L. (1999). Irrigation scheduling methods for potatoes in the northern great plains. American Society of Agricultural and Biological Engineers, 42: 351-360, https://doi.org/10.13031/2013.13366

Sale, P.J.M. (1979). Growth of potatoes (Solanum tuberosum L.) to the small tuber stage as related to soil temperature. Australian Journal of Agriculture Research, 30(4): 667-675, https://doi.org/10.1071/AR9790667

Samuel, B.ST. Clair, Erika, A. Studderthw, Marc L. Fischerz, Margaret S. Tornz, Stephanie A. Stuartw, Rohit Salvez, Dennis L. Eggett and Davdd. Ackerly (2009). Soil drying and nitrogen availability modulate carbon and water exchange over a range of annual precipitation totals and grassland vegetation types. Global Change Biology, 1862: 1365-2486, https://doi.org/10.1111/j.1365-2486.2009.01862.x

Sattelmacher, B., Marschner, H. and Kuhne, R. (1990). Effects of the temperature of the rooting zone on the growth and development of roots of potato (Solanum tuberosum). Annals of Botany, 65(5): 27-36, https://doi.org/10.1093/oxfordjournals.aob.a087974

Sattelmacher, B., Klotz, F. and Marschner, H. (1990). Influence of the nitrogen level on root morphology of two potato varieties differing in nitrogen acquisition. Plant and Soil, 123:131-137, https://doi.org/10.1007/BF00011258

Shahnazari, A., Liu, F., Anderson, M.N., Jacobsen, S.E. and Jensen, C.R. (2007). Effects of partial root-zone drying on yield, tuber size and water use efficiency in potato under field conditions. Field Crop Research, 100(1): 117-124, https://doi.org/10.1016/j.fcr.2006.05.010

Shahzad Jamaati-e-Somarin, RoghayyehZabihi-e-Mahmoodabad and AsgarYari (2010). Response of agronomical, physiological, apparent recovery nitrogen use efficiency and yield of potato tuber (Solanum tuberosum L.), to nitrogen and plant density. America-Eurasia Journal of Agriculture \& Environmental Science, 9 (1): 16-21, https://www.idosi.org/aejaes/jaes9(1)/3.pdf

Shirie Janagrad M., Tobeh, A., Hokmalipour, S., Sh.Jamaati-e-Somarin, Abbasi, A.and Shahbazi, K. (2006). Potato (Solanum tuberosum) response to drip irrigation regimes and plant arrangements during growth stages, pp.1-2.

Shock, C.C. (2003). Soil water potential measurement by granular matrix sensors. In Stewart, B.A. and Howell, T.A. (eds.) The Encyclopedia of Water Science. Marcel Dekker. pp. 899-903.

Shock, C.C., Eldredge, E.P. and Saunders, D. (2002). Drip irrigation management factors for Umatilla Russet potato production. Oregon State University Agricultural Experiment Station Special Report. 1038: 157-169.

Shock, C.C., Feibert, E.B.G., Saunders, L.D. (1998). Potato yield and quality response to deficit irrigation. Horticultural Science, 33: 655-659, http://agris.fao.org/agris-search/search.do?recordID=US1999002888

Simonne, E., Ouakrim, N. and Caylor, A. (2002). Evaluation of an irrigation scheduling model for drip-irrigated potato in Southeastern United States. $\begin{array}{lll}\text { HortScience, } & 37(1): & 104-107,\end{array}$ https://journals.ashs.org/hortsci/view/journals/hortsci/37/1/article-p104.pdf

Sinclair, T.R., Tanner, C.B. and Bennett, J.M. (1984). Water-use efficiency in crop legend potato yield and quality response to irrigation. HortScience, 38: 11171121.

Skewes, M. and Meissner, T. (1998). Irrigation benchmarks and best management practices for potatoes, Technical Report, Primary Industries and Resources SA, Adelaide, South Australia.

Speer, W., Ongprasert, S., Hegele, M., Wunshe, J.N., Muller, J. (2008). Yield and fruit development in mongo (Mangifera india L.V. Chok) under different irrigation regimes. Agriculture Water Management, 96 (4): 1-14, https://doi.org/10.1016/j.agwat.2008.09.020

Stark, J.C., Westermann, D.T., and Hopkins, B.G. (2004). Nutrient management guidelines for Russet Burbank potatoes. Bull. 840. Univ. of Idaho, Moscow.

Stefania De Pascale, Luisa Dalla Costa, SimonaVallone, Giancarlo Barbieri, Albino Maggio, (2011). Increasing water use efficiency in vegetable crop production. HortTechnology, 21(3): 301-308, https://doi.org/10.21273/HORTTECH.21.3.301

Steyn, J.M., Kagabo D.M. and Annandale, J.G. (2007). Potato growth and yield responses to irrigation regimes in contrasting season of a subtropical region. African Crop Science Conference Proceedings, 8: 1647-1651. 
Sun, D. and Dickinson, G.R. (1997). Early growth of six native Australian tree species in windbreaks and their effect on potato growth in tropical northern Australia. Forest Ecology and Management, 95(1): 21-34, https://doi.org/10.1016/S0378-1127(97)00005-4

Tanaka, A., Yamaguchi, J., Miura, S. and Tamaru, H. (1984). Comparison of fertilizer nitrogen efficiency among field crops. Soil Science and Plant Nutrition, 30(2): 199-208, https://doi.org/10.1080/00380768.1984.10434683

Taraka, A., Navasero, S.A., Garcia, C.V., Parao, F.T. and Ramirez, E. (1964). Growth habit of the rice plant in the tropics and its effect on nitrogen response. Technical Bulletin 3.The International Rice Research Institute, Los Nanos, Laguna, Philippines.

Tanner, C.B. (1981). Transpiration efficiency of potato. Agronomy Journal, 73: 5964, https://doi.org/10.2134/agronj1981.00021962007300010014x

Tanner, C.B., Weis, G.G. and Curwen, D. (1982). Russet Burbank rooting in sandy soils with pans following deep plowing. American Potato Journal, 59:107-112, https://doi.org/10.1007/BF02866365

Temmerman, L. De, Wolf, J., Colls, J., Bindi, M., Fangmeier, A., Finnan, J., Ojanpera, K. and Pleijel, H. (2002). Effect of climatic conditions on tuber yield (Solanum tuberosum L.) in the European 'CHIP' experiments. European Journal of Agronomy, 17(4): 243-255, https://doi.org/10.1016/S1161-0301(02)00064-3

Timm, H. and Flockner, W.J. (1966). Responses of potato plants to fertilization and soil moisture under induced soil compaction. Agronomy Journal, 58: 153-157, https://doi.org/10.2134/agronj1966.00021962005800020009x

Tsegaw, T. (2006). Response of potato to paclobutrazol and manipulation of reproductive growth under tropical condition. Department of Plant Production and Soil Science. Faculty of Natural and Agricultural Sciences, University of Pretoria. South Africa.

van Loon, C.D. (1990). The effect of water stress on potato growth, development and yield. American Potato Journal, 58(1): 51-69, https://doi.org/10.1007/BF02855380

Waddell, J.T., Gupta, S.C., Moncrief, J.F., Rosen, C.J. and Steele, D.D. (1999). Irrigation and nitrogen management effects on potato yield, tuber quality, and nitrogen uptake. Agronomy Journal, 91: 991-997, https://doi.org/10.2134/agronj1999.916991x

Walker, C.D. and Lance, R.C.M. (1991). Silicon accumulation and 13C composition as indices of water-use efficiency in barley cultivars. Australian Journal of Plant Physiology 18(4): 427- 434, https://doi.org/10.1071/PP9910427

Wang, Feng-Xin, Kang, Yaohu Liu, Shi-Ping (2006). Effects of drip irrigation frequency on soil wetting pattern and potato growth in North China Plain. Agricultural Water Management, 79(3): 248-264, https://doi.org/10.1016/j.agwat.2005.02.016

Wheeler, R.M., Tibbitts, T.W. and Fitzpatrick, A.H. (1989). Potato growth in response to relative humidity. HortScience, 24: 482-484, https://www.ncbi.nlm.nih.gov/pubmed/11540907

Westermann, D.T. (2005). Nutritional requirements of potatoes. American Journal of Potato Research, 82: 301-307, https://doi.org/10.1007/BF02871960

Western Potato Council, (2003). Botany of the potato plant. Adaptation from Guide to Commercial Potato Production on the Canadian Prairies.

Wilcox, G.E. and Hoff, J. (1970). Nitrogen fertilization of potatoes for early summer harvest. American Potato Journal, 47: 99-102, https://doi.org/10.1007/BF02864811

Wright, J. L. and Stark, J.C. (1990). Potato. IN B.A. Stewart and D.R. Nielson (eds.) Irrigation of agricultural crops. ASA CSSA SSSA. pp. 859-888.

Wu, F.Z., Bao, W.K., Zhou, Z.Q. and Wua, N. (2009). Carbon accumulation, nitrogen and phosphorus use efficiency of Sophora davidii seedlings in response to nitrogen supply and water stress. Journal of Arid Environment, 73(12): 10671073, https://doi.org/10.1016/j.jaridenv.2009.06.007

Yibekal, A. (1998). Effects of Nitrogen and phosphorus on yield and yield components, and. some quality traits of potato (Solanum tuberosum L.) at Wondo Genet area. M.Sc. Thesis, Alemaya University of Agriculture, Ethiopia, pp. 82.

Yuan, B.Z., Nishiyama, S. and Kang, Y. (2003). Effects of different irrigation regimes on the growth and yield of drip-irrigated potato. Agriculture Water $\begin{array}{ll}\text { Management, } & \text { 63(3): }\end{array}$ https://doi.org/10.1016/S0378-3774(03)00174-4

Zelalem, A., Tekalign, T. and Nigussie, D. (2009). Response of potato (Solanum tuberosum L.) to different rates of nitrogen and phosphorus fertilization on vertisols at DebreBerhan, in the central highlands of Ethiopia. African Journal of Plant Science, 3 (2): 016-024, http://www.academicjournals.org/app/webroot/ article/article1380021003_Zelalem\%20et\%20al.pdf 